\title{
AN ANALYSIS OF LASER-WELDED NiCr-Ir AND NiCr-Pt MICRO JOINTS ON SPARK PLUG ELECTRODES IN BIOGAS-FUELLED ENGINES
}

\begin{abstract}
The paper deals with the laser beam welding of tips to central and side spark plug electrodes made of a nickel-chromium alloy. The tips attached to the central electrodes were made from a solid iridium wire $0.8 \mathrm{~mm}$ in diameter and $2 \mathrm{~mm}$ in length, while the tips connected to the side electrodes were made from a platinum wire $1.5 \mathrm{~mm}$ in diameter and $0.25 \mathrm{~mm}$ in thickness. In both cases, accurate positioning of the tips was required before they were resistance welded to the electrodes. Then, a fillet weld was produced with an Nd:YAG laser using single, partly overlapping conductive pulses. The laser welding was performed at different laser power levels and pulse durations. Metallographic sections of the joints were prepared to observe changes in the microstructure and determine their correlation with the changes in the process parameters. The results were used to select appropriate welding parameters for the materials joined. The microscopic analysis indicated welding imperfections such as micro cracks at the interface between the elements joined. The tips welded to the spark plug electrodes can help extend the service life of spark plugs in highly corrosive environments.
\end{abstract}

Keywords: Microwelding; Laser; Spark plugs; Refractory materials; Biogas

\section{Introduction}

Being one of the most common sources of renewable energy, along with wind, solar, and geothermal energy, biogas can be used as a fuel to generate electrical energy in actuators for spark-ignition engines. Because of the highly corrosive properties of the products of biogas combustion, conventional spark plugs are considered uneconomical for this technology; nickel electrodes wear out too quickly. The service life of spark plugs can be extended by covering the electrodes with tips made from special metals or metal alloys resistant to high-temperature corrosion, i.e. iridium, yttrium, platinum, and platinum-iridium $[1-5,13]$. One of the conditions for the reliability of spark plugs operating in biogas surroundings is to achieve the smallest possible thermal resistance while producing a tip-central electrode connection. When the thermal resistance is high, it is difficult to remove heat from the tip to the central electrode. This results in an increase in the temperature of the tip, and, accordingly, sooner erosive wear.

As there has been a considerable progress in the miniaturization of elements in contact, the requirement for welding small-size elements is now common [1]. Research concerning spark plugs focuses on two main methods of joining tips to electrodes: resistance welding and laser welding, with the latter becoming increasingly popular. Laser micro welding is used to eliminate or reduce defects occurring in joints produced by resistance welding. The major disadvantage of resistance welding is that it does not provide a metallurgical connection between the spark plug electrode and the tip. Because of a large difference in the melting point between the material used for the tip and that used for the central electrode, the connection is adhesive in nature and has higher thermal resistance. The use of a laser beam, which is capable of melting the materials to be joined, results in the material mixing, which provides a metallurgical connection [6-14].

The aim of the research project run by the Laser Processing Research Centre of the Kielce University of Technology is to extend the service life of spark plugs by using solid iridium tips. A preliminary experimental investigation was conducted to produce solid iridium tips for central electrodes by applying pulsed laser micro welding.

\section{Material and method}

This paper presents a research project that investigates the fillet micro welding of tips to nickel-chromium spark plug electrodes. The tips were in the form of solid iridium and platinum wires, which were joined to the central and side electrodes, respectively. The tips used in the experiments were precision

\footnotetext{
KIELCE UNIVERSITY OF TECHNOLOGY, DEPARTMENT OF TEROTECHNOLOGY AND INDUSTRIAL LASER SYSTEMS, FACULTY OF MECHATRONICS AND MECHANICAL ENGINEERING, $7^{\text {th }}$ TYSIACLLECIA P.P. AV. 25-314 KIELCE, POLAND

** MILITARY UNIVERSITY OF TECHNOLOGY, INSTITUTE OF MOTOR VEHICLES AND TRANSPORTATION, FACULTY OF MECHANICAL ENGINEERING, 2 GEN. SYLWESTRA KALISKIEGO STR., 00-908 WARSAW 49, POLAND

\# Corresponding author: tofil@tu.kielce.pl
} 
cut into sections $2 \mathrm{~mm}$ in length and $0.8 \mathrm{~mm}$ in diameter for the central electrode and sections $1.5 \mathrm{~mm}$ in diameter and $0.25 \mathrm{~mm}$ in thickness for the side electrode. The tips were then placed at the face of the electrodes, as shown in Fig. 1. It was necessary first to apply resistance welding to join the tips to the electrodes so that the accuracy of laser micro welding would be higher. The elements to be joined were accurately positioned relative to the laser beam using a specially developed positioning system.

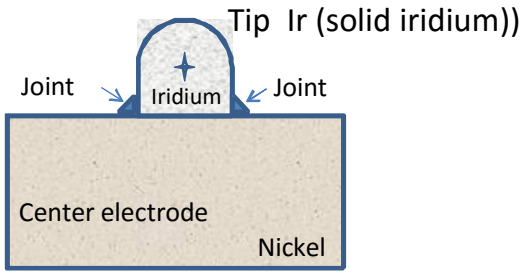

a)
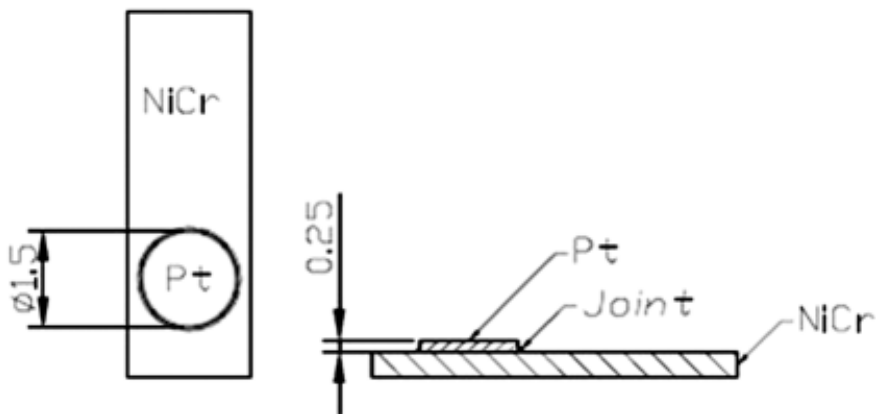

b)

Fig. 1. Schematic diagrams of the laser micro welded joints a) between iridium tips and central electrodes and b) between platinum tips and side electrodes

The tips were micro welded using two different laser welding systems by Rofin. The welded joints for central electrodes were produced with a Rofin Integral welding machine at the Warsaw-based Military University of Technology (abbreviated to WAT in Polish). The system includes an Nd:YAG laser generating a beam with a wavelength of $1064 \mathrm{~nm}$ and a focus diameter of $0.4 \mathrm{~mm}$. The laser system with five degrees of freedom can operate in a pulsed or quasi-continuous wave mode. The maximum laser power is $12 \mathrm{~kW}$ while the pulse duration ranges from 0.3 to $50 \mathrm{~ms}$. The welding of side electrodes was performed by means of an Nd:YAG BLS 720 laser generating a beam with a wavelength of $1064 \mathrm{~nm}$ and a focus diameter of $0.7 \mathrm{~mm}$. The system operating in the pulsed or quasi-continuous mode is capable of generating $150 \mathrm{~W}$ average power, $7 \mathrm{~kW}$ peak power, $35 \mathrm{~J}$ pulse energy at the pulse duration ranging from 0.3 to $20 \mathrm{~ms}$ and frequency up to $300 \mathrm{~Hz}$. The experiments were conducted using a laser facility at the Laser Processing Research Centre (abbreviated to CLTM in Polish) of the Kielce University of Technology. The two systems are presented below in Fig. 2.
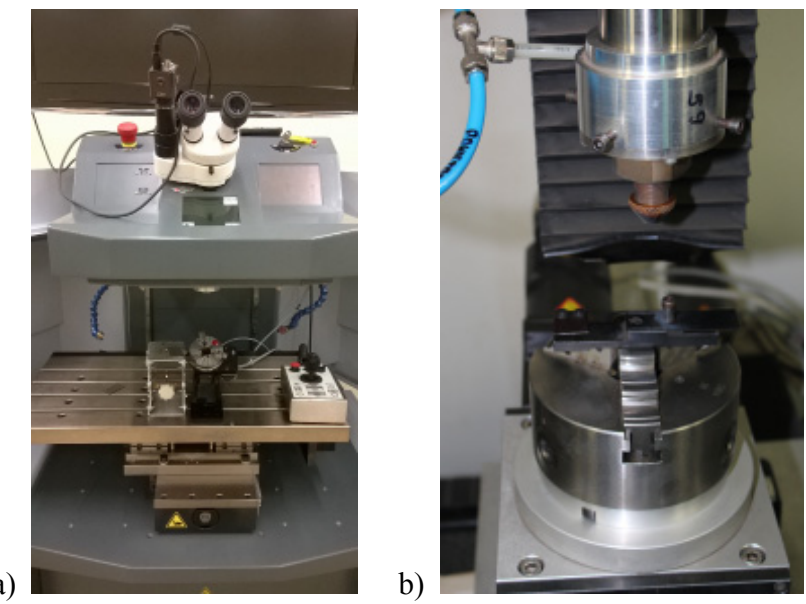

Fig. 2. Equipment used for the welding of tips to spark plug electrodes: a) Rofin Integral (WAT), b) Rofin BLS 720 (CLTM)

The joints were produced by laser beam welding using single partly overlapping pulses on both sides of the tip along the iridium or platinum wire and the electrode, as shown in the diagram in Fig. 1. The weld area was protected by argon shielding gas.

The tips were welded to the electrodes using different pulse durations and beam power levels. Transverse metallographic sections of the welded joints were prepared and observed under a metallographic microscope and a scanning electron microscope. The fusion zones were also analyzed on the basis of EDS spectra.

The preparation of the metallographic sections of the laser welded joints involved first mounting the materials in conductive resin to ensure correct SEM analysis and then grinding them with progressively finer grit paper (from 80 up to 1200). Each change into a finer grade required changing the grinding angle by $90^{\circ}$. Then, the specimens were rinsed and dried to remove abrasive residue. Finally, the ground specimens were polished using a lubricant and a diamond solution, with the grain sizes being $3 \mu \mathrm{m}$ and $1 \mu \mathrm{m}$, respectively.

The analysis of the welding impacts involved visual assessment of the joint quality using an Olympus SZX10 stereoscopic microscope with magnification up to $126 \times$ and a Hirox KH-8700 digital microscope with a magnification range from 35 to $5000 \times$. Examples of joints between spark plug tips and electrodes formed by resistance welding (prior to laser welding) are shown in Fig. 3.

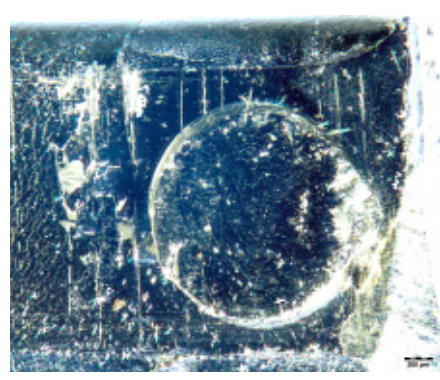

a)

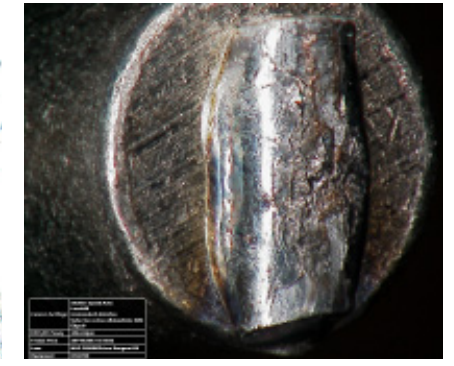

b)
Fig. 3. Images of spark plug electrodes after electric resistance welding (before laser welding): a) side electrode magnified $64 \times$, b) central electrode magnified $100 \times$ 
The parameters of the laser welding of tips to side electrodes were selected experimentally by observing the changes in the process parameters. For the operation of the BLS 720 laser, the power was controlled by changing the voltage supplied to the lamps, pulse frequency, pulse duration and feed rate during welding. The weld area was protected by argon shielding gas. The best effects were achieved at the following parameters: $50 \mathrm{~W}$ laser power, which corresponds to $600 \mathrm{~V}$ lamp voltage, $5 \mathrm{~Hz}$ frequency, and $120 \mathrm{~mm} / \mathrm{min}$ feed rate.

The parameters of the laser micro welding of tips to central electrodes were also determined experimentally. As provided in Table 1, the parameters are: laser power $P$, pulse duration $t$, laser energy density at the surface $D$, and beam energy per pulse $E$.

TABLE 1

Selected parameters of the laser micro welding of tips to central electrodes

\begin{tabular}{|c|c|c|c|c|}
\hline $\begin{array}{c}\text { Specimen } \\
\text { number }\end{array}$ & $\begin{array}{c}\text { Laser power } \\
{[\mathbf{k W}]}\end{array}$ & $\begin{array}{c}\text { Pulse duration } \\
{[\mathbf{m s}]}\end{array}$ & $\begin{array}{c}\text { Energy density } \\
{\left[\mathbf{J} / \mathbf{c m}^{2}\right]}\end{array}$ & $\begin{array}{c}\text { Energy } \\
{[\mathbf{J}]}\end{array}$ \\
\hline 1 & 2.02 & 3.0 & 3860 & 4.85 \\
\hline 2 & 2.50 & 3.0 & 4777 & 6.00 \\
\hline 3 & 2.02 & 3.5 & 3503 & 5.66 \\
\hline
\end{tabular}

\section{Results and discussion}

The microscopic analysis was performed using a HIROX KH-8700 digital microscope and a JEOL JSM 5400 scanning electron microscope equipped with an energy dispersive spectrometer.

This paper discusses selected results illustrated in Figs. 4-6.

Figure 4 shows images obtained with the OLYMPUS SZX10 and HIROX KH-8700 microscopes: a) a platinum tip joined to a side electrode and $\mathrm{b}$ ) an iridium tip joined to the face of a central electrode. There is a clear difference in the joint production technique. The tip on the side electrode is spot welded and the welds slightly overlap forming separately solidifying weld pools. The tip on the central electrode, on the other hand, is welded by continuously moving the base metal (which results in considerable overlapping of pulses) and the solidification marks form a uniform sequence of arcs. Figure $4 \mathrm{c}$ shows an image of the electrodes in the spark plug.

Figures 5 and 6 show metallographic cross-sections of the welds obtained with the JEOL JSM 5400 scanning electron microscope.

Figure 5 presents metallographic specimens of a side electrode with a platinum tip. As can be seen both on the left and right sides of the tip, the mixing of platinum with the base metal was better than that obtained for iridium tips (Fig. 6). This may be due to the fact that the melting point of nickel is $1455^{\circ} \mathrm{C}$, which is similar to the melting point of platinum, i.e. $1768^{\circ} \mathrm{C}$. However, it is nearly $1000^{\circ} \mathrm{C}$ higher than the melting point of iridium $\left(2447^{\circ} \mathrm{C}\right)$. When iridium reaches its melting point, nickel is almost at its boiling point $\left(2913^{\circ} \mathrm{C}\right)$. As a result, its content in the weld is lower. There are clear profiles of the round tips attached to the central electrode by resistance welding.

It can also be seen that there is no fusing of the materials in the central part of the joints. The welded connections are characterized by a very thin diffusion zone. At the top, the elements joined are partly fused by the laser beam. The fusion zones differ depending on the point where the laser beam impacts the metal. Whenever the beam covers the area of the electrode and the tip, the area of the base metal melted is larger than the area of the tip melted. From the comparison of the sizes of the melted areas with the values of the laser micro welding parameters provided in Table 1 it is clear that the size of the fusion zone is dependent mainly on the pulse duration $\tau$. When the pulse duration was the longest, $\tau=3.5 \mu \mathrm{s}$, and the laser power was $P=2.02 \mathrm{~kW}$, the fusion zone was larger in size. For the above values of the parameters $P$ and $\tau$, the beam energy per pulse was $E=5.66 \mathrm{~J}$, with the value being an average.

As can be seen from Fig. 5, the fusion zones are affected by the convection movements; this results in different contents of platinum. In Fig. 6, the lighter areas are zones richer in platinum or iridium. Figure $5 \mathrm{~b}$ shows small cavities caused by the trapping of gases released by the metal. From Fig. 6 it is evident that the mixing of the materials is incomplete and that there are micro cracks in the welds extending to the base metal. These phenomena indicate that, irrespective of the pulse energy, the time that the fusion zone was in the liquid state was

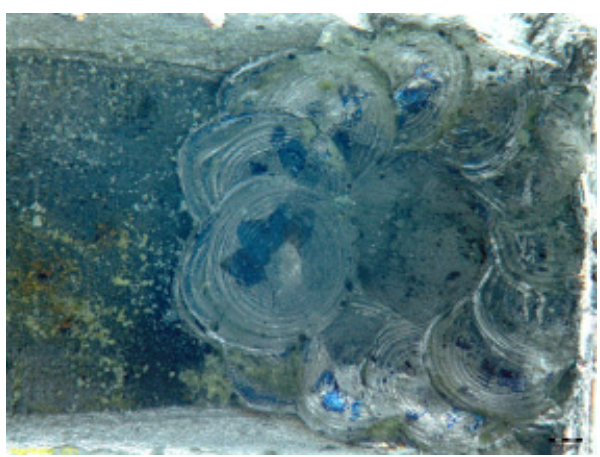

a)

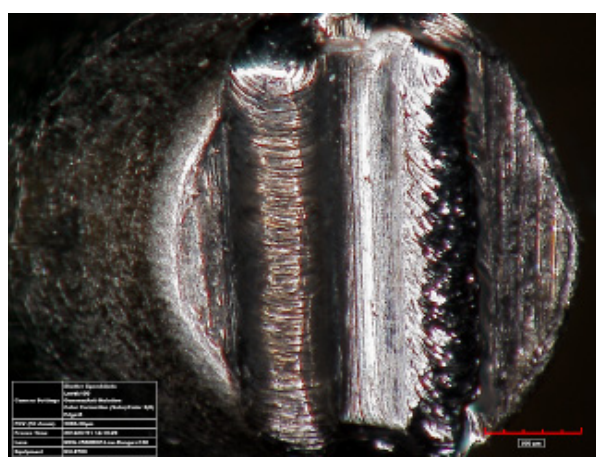

b)

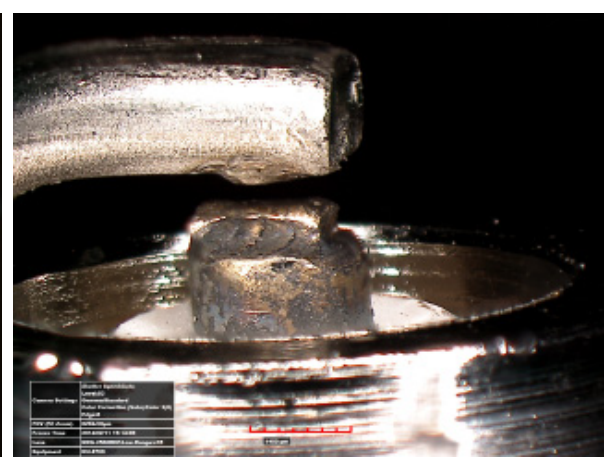

c)

Fig. 4. Images of spark plug electrodes with micro welded tips: a) fusion zone on the side electrode magnified $50 \times$, b)fusion zone on the central electrode magnified $100 x, c)$ spark plug electrodes magnified $100 \times$ 
1166

a)

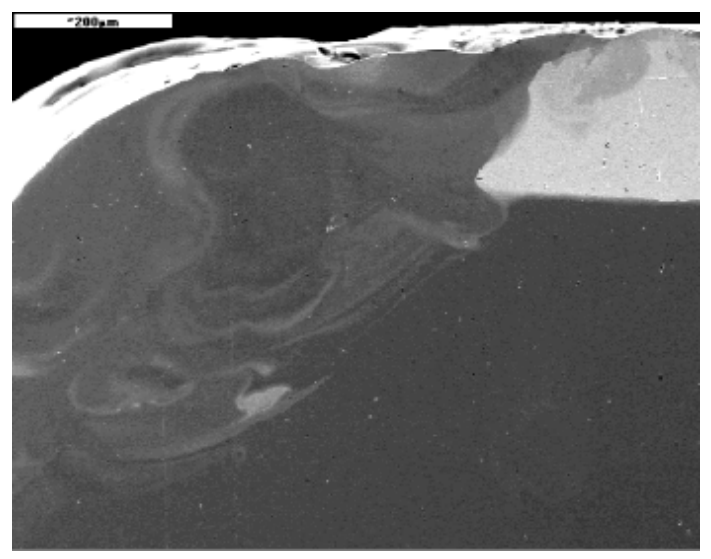

c)

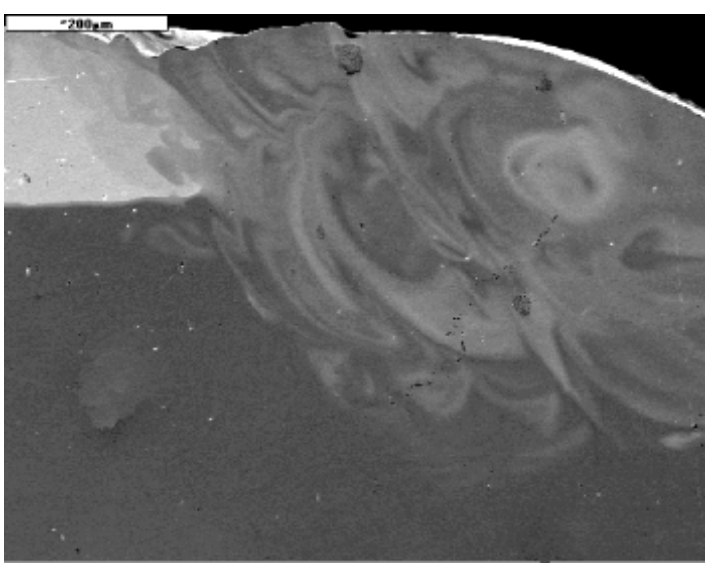

b)

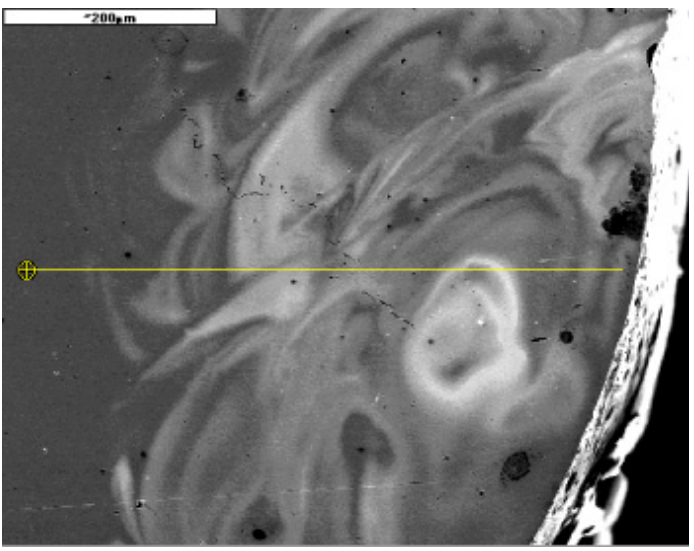

d)



Fig. 5. Images of welded joints between side electrodes and platinum tips magnified 150×: a) left edge of the joint, b) right edge of the joint, c) fusion zone of the NiCr-Pt connection, d) EDS spectra

a)

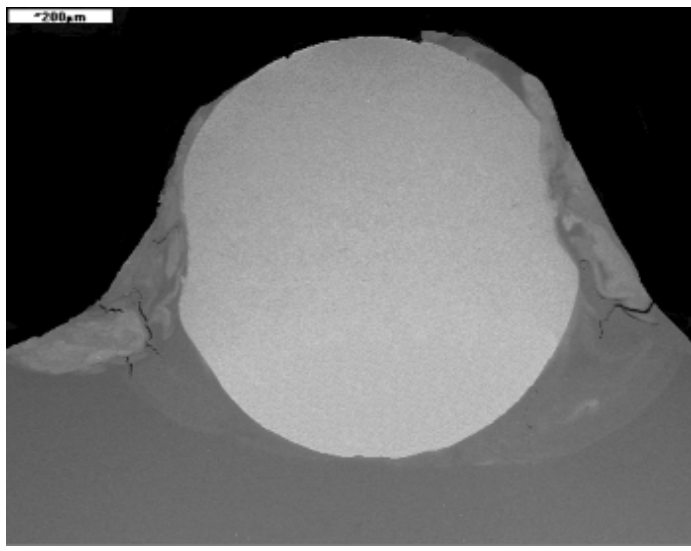

c)

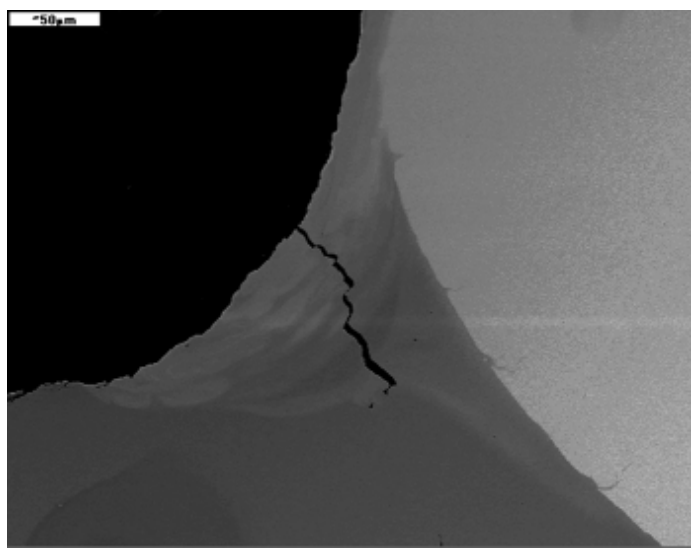

b)



d)

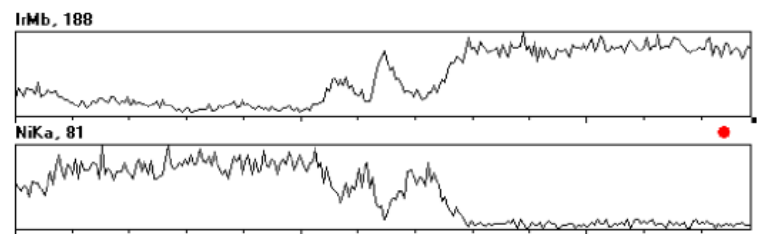

Fig. 6. Micrographs of polished cross-sections of the central electrode: a) magnified. $75 \times$, b) view of a microcrack magnified $350 \times$, c) fusion zone of the NiCr-Ir connection, d) EDS spectra 
probably too short to ensure complete mixing of the materials and compensate for stresses set up during welding. The occurrence of gas voids and micro cracks in the molten areas is an unfavourable phenomenon. Material discontinuities may lead to local increases in thermal resistance and, in consequence, an increase in the temperature of the tip. Another phenomenon attributable to the presence of micro cracks is stress concentration. It gives rise to the growth of micro cracks, which may lead to material failure, and the detachment of the tip from the central electrode.

\section{Conclusions}

The following are conclusions drawn from the results of the preliminary experimental research on the pulse laser micro welding of tips to spark plug electrodes:

- the fusing of the tips with the electrodes was achieved at different pulse laser welding parameters;

- $\quad$ in the fusion zone, the mixing between the tip material and the base metal, i.e. the electrode material, is incomplete;

- the size of the fusion zone is largely dependent on the duration of the pulse creating the weld;

- welds generated by single laser pulses contain micro cracks, irrespective of the welding parameters used.

\section{Acknowledgements}

The research reported herein was supported by a grant from the National Centre for Research and Development (No. PBS1/B5/13/2012).

\section{REFERENCES}

[1] Sz. Tofil, B. Antoszewski, Problemy mikrospawania laserowego elementów z Ni-Cr, W oraz stopów Pt. Warstwa Wierzchnia Technologicznie Kształtowana Gorzów Wlkp. (2011).
[2] N. Radek, R. Ślusarczyk, Wpływ parametrów spawania laserowego na własności mechaniczne spoiny. Przegląd Spawalnictwa 4, 18-20 (2002).

[3] A. Klimpel, Spawanie zgrzewanie i cięcie metali WNT, Warszawa, (1999).

[4] P.M Powel, Laser-Based Micromachining Gets Practical. Photonics Spectra 70, (2003).

[5] R. Domański, Promieniowanie laserowe-oddziaływanie na ciała stałe. WNT, Warszawa, (1990).

[6] N. Radek, B. Antoszewski, Influence of laser treatment on the properties of electro-spark deposited coatings. Kovove Materialy-Metallic Materials 47(1), 31-38 (2009).

[7] N. Radek, Determining the operational properties of steel beaters after electrospark deposition. Eksploatacja i Niezawodność - Maintenance and Reliability 4, 10-16 (2009).

[8] N. Radek, K. Bartkowiak, Performance properties of electro-spark deposited carbide-ceramic coatings modified by laser beam. Physics Procedia (Elsevier) 5, 417-423 (2010).

[9] J. Pilarczyk, Poradnik inżyniera - Spawalnictwo. Tom 1. Warszawa WNT (2003).

[10] W. Danilczyk, St. Kruczyński, M. Stępniewski, R. Wołoszyn, Ocena połączeń Pt-NiCr na elektrodach świecy zapłonowej. VII Międzynarodowa Konferencja Naukowo-Techniczna „Logistyka, systemy transportowe, bezpieczeństwo w transporcie“ - LOGITRANS 2010, Szczyrk.

[11] H.T. Lin, M.P. Brady, R.K. Richards, D.M. Layton, Characterization of erosion and failure processes of spark plugs after filed service in natural gas engines. Wydawnictwo WEAR (1063-1067) (2005).

[12] S. Javan, S.V. Hosseini, S.Sh. Alaviyoun, An experimental investigation of spark plug temperature in bi-fuel engine and its effect on electrode erosion. International Journal of Automotive Engineering 2(1) (2012).

[13] G.W. Shoobert, Iridium electrodes increase spark plug life. Platinum Metals Rev. (1962).

[14] B. Grabas, Sz. Tofil, Mikrospawanie laserowe nakładek irydowych na elektrodę rdzeniową świecy zapłonowej - Sympozjum Katedr i Zakładów Spawalnictwa „Nowoczesne zastosowania technologii spawalniczych”, Brenna 17-18 czerwca 2014 